ALDON D. BELL

\title{
ADMINISTRATION AND FINANCE OF THE REFORM LEAGUE, I865-I867
}

In the first months of 1865 artisan and middle class Reformers in London established the Reform League with the publicly stated political goals of "manhood suffrage and the ballot". ${ }^{1}$ Reflecting a new political awareness among artisan workingmen as well as a realization that workingmen and sympathetic bourgeois Reformers might achieve more when agitating together, the League resulted from experiences and associations in several recent working class and bourgeois campaigns, concerns, and agitations. London artisans, for instance, had been involved in trade unions (both amalgamated and local), the London Trades Council, Trades Union Manhood Suffrage and Vote by Ballot Association, Workingmen's Garibaldi Committee, Universal League for the Improvement of the Working Classes, and International Working Men's Association ("First International"). They also joined organizations and campaigns more

1 The Howell Collection, which includes the papers of the Reform League, is located at the Bishopsgate Institute, London E.C. 2. League papers include the minute books for the various councils and executives, ledgers, account books, carbon books of letters sent, and some letters received. The boxes of miscellaneous materials include clippings, pamphlets printed by the League, odd notes of all kinds (including plans for demonstrations), and posters. Howell's manuscript autobiography and his sketches of personalities are also in the collection. I have filled out information from these sources by culling reports in many London and provincial newspapers. The most useful are the Bee-Hive, Commonwealth, and Morning Star in London, and the Birmingham Journal, Manchester Examiner and Times, Leeds Express, Newcastle Chronicle, and Glasgow Sentinal. Many other newspapers have also contributed to my file of information on the League and its branches. Some particularly useful secondary sources are: Frances Emma Gillespie, Labor and Politics in England, 1850-1867 (Durham, N. C., 1927); Sidney and Beatrice Webb, History of Trade Unionism (London, I894); Henry Pelling, A History of British Trade Unionism (London, 1963); Joseph Park, The English Reform Bill of 1867 (New York, 1920); Asa Briggs, Victorian People (London, 1954); Royden Harrison, Before the Socialists: Studies in Labour and Politics 1861-1881 (London, 1965). Many of the essays in Prof. Harrison's book appeared in this journal. I should also like to acknowledge all the information and guidance I have received at one time or another from Professors Asa Briggs, Henry Pelling, and Francis H. Herrick, with each of whom I have been a student. 
closely associated with the middle classes: temperance groups, Liberation Society, National League for Polish Independence, Emancipation Society, and Ballot Society. Here the artisans met bourgeois Reformers who helped establish and finance the Reform League.

Several factors converged in early i 86 , to make the League possible. Palmerston's foreign policy, especially regarding Poland and the United States, disgusted many. Also, Palmerston firmly controlled domestic politics, and could frustrate Reformers in Parliament by working with Tories against his occasionally obstreperous affiliates the Radicals, Peelites, and Reforming Whigs. Among artisans several industrial and economic problems since 1859 underscored the importance of political participation: the status of trade unions, industrial accidents, general working conditions, working class housing, adulteration of foods. A parliamentary election must be held by $\mathrm{x} 866$; chances were good that the Government would choose sometime in 1865 , which it eventually did. Finally, Palmerston was 81 years of age. Time was ripe enough to give the League an encouraging though not solidly impressive start.

In London the League at first restricted itself to broadening the base of the organization with branches, and then influencing the elections of metropolitan M.P.'s in the summer of i $86 \mathrm{~g}$. The election of Thomas Hughes (Lambeth), John Stuart Mill (Westminster), and Alderman Lusk (Finsbury) pleased the League; artisans had worked particularly hard for Hughes and Mill. But an historical circumstance gave real scope to the League in October: Palmerston died. Henceforth, the League supported the Reform effort of the Earl Russell's Government, which had Gladstone as Chancellor of the Exchequer and Leader of the House.

Persistent work kept League demonstrations and public meetings a part of Reform developments, but initiative was entirely in the House of Commons. Then, in June, 1866, Russell's weak Government was forced out of office on the issue of Reform. The League called a mass meeting in Hyde Park on 23 July, and was aided by the Tory Government's endorsement of the previous Government's decision to refuse permission to use the Park for political purposes. Leaguers saw their confrontation with authorities at the gates of the Park, meant to be peaceful, develop into disorders. Park railings collapsed and were ripped up, the Queen's flowers were trampled, stones were thrown at the police, some politicians lost their window panes, picking of pockets and petty thievery increased, and youth gangs enjoyed themselves more openly in the streets for four days: in short, the incident for one revealing moment weakened public order in London. Public excitement, and therefore the League's 
opportunities, consequently increased. It is hard to judge who was more surprised and impressed by the Hyde Park "riots", the Derby Government or the League itself.

After its exhilarating July week the League expanded its London and provincial activities, and worked to convince Parliament and the Tory Government that London had the central direction of the developing agitation. London officers, councillors, and delegates nominally led the "national" organization, but major provincial centers worked out their own regional agitations with few ties with London beyond general principles. Manchester, Birmingham, Leeds, Newcastle, and Glasgow formed "departments" of the League which reflected regional politics and exnflicts, and socio-economic patterns different from London's. London, while wanting regional initiative which would expand the League, found Birmingham's assertive efficiency verging on rivalry. Londop did coordinate the League in late 1866 and I867, but exert'd real initiative and leadership only when the question of public meetings in the Royal Parks was an issue in May and August, I 867 .

London's League recognized, though indistinctly, three major functions: I) assuming real leadership and direction for the London metropolitan area, 2) coordinating under the name of the League the manhood suffrage effort throughout Great Britain, and 3) fostering the illusion of London's national control in order more effectively to influence Parliament, the Government, and politically-conscious public. Historically, the London League performed another crucial function: with difficulty it began and sustained a nominally national agitation for eighteen morihs until the provincial centers joined in. Upon that base the Reforiners, and especially the manhood suffrage Reformers, built an agitation which could take some advantage of historical circumstances - the death of Palmerston, the fall of Russell's Government, the financial panic of 1866 , the outbreak of cholera in I866.

Because of the events of 1866 and 1867 , many aspects of the Reform League's history are important and interesting. This essay concerns itself particularly with one special aspect, the structure and finance of the national League.

\section{II}

The men who established the League in February-April, i 865, outlined a simple structure. Clearly, though not stated explicitly, the total membership was the source of authority. The Rules of the League, 
adopted at St. Martin's Hall on 23 March, do not state how the membership shall be represented institutionally. ${ }^{1}$ Initially, as in the case of the adoption of the Rules themselves, public meetings decided matters put to them by the leadership. But throughout its history the League worked out no standard solution for the representative or delegate institution which would be the link between those who managed the affairs of the organization and those who made up the total membership. Once the executive unit was somewhat defined, it chose a variety of means to draw authority from the membership. The executive used for this purpose public meetings, large representative councils elected by public meetings and by League branches, and delegate assemblies which included non-Leaguers. The choice depended upon the press of events.

For the management of the League's structure the Rules stated that "the affairs of the League shall be conducted by a president, vice-presidents, and an executive committee, with the assistance of secretaries and a treasurer." The small units which functioned as the "executive committee" changed in name and personnel throughout the months of the agitation, for the League had difficulty discovering any exact formula for efficiency and responsibility. From among their own numbers the members of the executive appointed special committees to direct League projects or to supervise one executive function, such as finances.

The officers were directly responsible to, but active members of, the executive. The public meeting of 23 March 1865 elected Edmond Beales president. The executive itself appointed George Howell secretary on 24 May, just as it had earlier elected A. J. Nicholay treasurer. In August, 1866, William Dell was appointed as "Joint Treasurer" with Nicholay, who had been ill much of the first year. Beales was a barrister, Dell an upholsterer, and Nicholay a City businessman (furrier?): all middle class. Howell was an artisan, a bricklayer. Except for the first eight, the honorary vice-presidents were appointed by the executive. The League had over $\mathrm{z} 20$ by the summer of 1867 . All were middle class, and some few such as E. D. Rogers, J. Baxter Langley, and Charles Bradlaugh were also elected members of the executive. The original Rules had given vice-presidents the right to sit on the "executive committee", but when the League had finally delineated a general council and an executive, this right was interpreted in terms of the general council only.

A study of the institutional development of each segment provides

1 Bee-Hive and Miner and Workman's Advocate (later The Commonwealth), 25 March I865. The Rules were usually reprinted in League pamphlets. 
more understanding of the organization. The representative assembly suffered the most complex and confusing development. The first public meeting of 23 February 1865 was, in effect, the first general and representative assembly of the League, for this meeting established the organization by the simple act of resolving itself into "an association to be called "The Reform League"' with the objectives of manhood suffrage and the ballot. The meeting also appointed Robert Hartwell, the editor of the Bee-Hive, as provisional secretary; fixed the annual subscription at one shilling; and asked the middle class to cooperate "through" Beales and T. Mason Jones. Finally, it elected an organizing committee of twenty-nine members. The participants in the meeting made a conscious effort to divide the positions equally between artisan and middle class Reformers. ${ }^{1}$

Two further public meetings served as continuations of the first. The meeting of I6 March, disappointed and annoyed at John Bright's refusal to endorse manhood suffrage or actively to support the new League, appointed a new organizing committee with Beales as chairman, and asked the committee to write rules for the League. ${ }^{2}$ On 23 March the third of these initial public meetings accepted the proposed rules, elected Beales president, invited fifteen men to become honorary vice-presidents (eight accepted), and elected an "Executive Council" of thirty-nine members. ${ }^{3}$

These arrangements were not satisfactory for the efficient working of the League as it grew in size. Soon after 23 March the Council appointed a smaller executive from its own members, but uncertain institutional relationships and personal rivalries forced the Council to abolish the small group. By the end of August, I 86, the Executive Council was calling itself the "Executive Committee", and had doubled in size to around eighty. ${ }^{4}$ It had always been large for real executive purposes, and through the months it readily added to itself active Reformers who accepted League principles. Even though the hard inner core of the large Committee was composed of LTC men and their supporters, the "Junta", homogeneity alone could not guarantee efficient administration. In October, therefore, E. D. Rogers suggested that the Executive Committee restrict itself to twenty-four members. The Committee accepted Rogers' proposal, and thus became a small, manageable executive unit. This new executive then created an

1 Bee-Hive, 25 February 1865 .

a Ibid., 18 March 1865 . More details of the Radley Hotel meeting were given in an article written by "A Member of the Council" in Bee-Hive, ro November 1866.

s Ibid., 25 March.

- Accumulated information from the Minutes confirms this statement. 
"Executive Council", a sort of representative assembly which shortly came to be called the "General Council". ${ }^{1}$

The General Council restricted its membership to qualified delegates of League branches. There were in late 186 ; ten or twelve metropolitan branches, another half dozen preliminary branch committees in London, and about twenty provincial branches, each of which could send two delegates. Beales also enjoyed the prerogative of seating in the General Council delegates from trade unions, temperance societies, and friendly and benefit societies which accepted League principles. He regularly used his prerogative, without criticism. ${ }^{2}$

Events in 1866 increased the pace of the agitation, size of the League, and problems of organization. The executive arrangements were inadequate, and the General Council was asked in September to elect by ballot a new executive of fifteen from among its members. In October E. D. Rogers proposed that regular absentees on the General Council be struck off the roll, and that each branch be allowed one delegate only. ${ }^{3}$ These reforms accepted, both the larger assembly and its executive were more manageable. A League pamphlet in December listed 59 members of the General Council.

In the first six months of 1866 the General Council usually met monthly; in the last six months, weekly. Throughout the year the Council initiated little: a few demands for public meetings, and some criticism of the secretary, Howell, by the Potter faction. ${ }^{4}$ Otherwise it was docile. In 1867 the General Council tried to re-assert its supposed control over the executive which it had originally elected but which was rapidly absorbing all real power over the League. In January the Council elected a special committee to take over the planning of the great demonstration at the opening of Parliament. The executive treated this action as a vote of censure, asked the General Council to elect a new executive immediately, but then was confirmed in office through the February demonstration in question. The

1 Minute Books, 6 and 27 October.

2 Ibid., Executive Council, 17 November and 8 December 1865.

- Ibid., Executive Committee, 3 r October 1866.

4 George Potter and the LTC had been rivals in London trade union politics since $186 \mathrm{I}$, and the two warred constantly until $\mathrm{I} 868$, when a settlement was made. See Stephen Coltham, "The Bee-Hive Newspaper: Its Origins and Early Struggles", in: Essays in Labour History, ed. by Asa Briggs and John Saville (London, 1960), pp. 174-204.

Because of the nature of this study, and the material used, the comments on Potter are not, I realize, favorable. Other material might prove Potter a different sort of leader and personality than I indicate, though $I$ have also been influenced in my characterization by Coltham's essay. 
General Council rescinded its election of a demonstration committee. ${ }^{1}$ Faced with the prospect of losing the executive and re-electing another just before the opening of Parliament, the General Council gave way. Though the regular election of a new executive took place in February, the General Council did not take initiative within the League structure. In fact, the General Council itself was superceded from February until May, I867; the executive now used delegate meetings as the general assembly and source of approval for what the executive had done. League branches, trade unions, friendly and benefit societies, temperance organizations, cooperatives, and other reform associations all sent delegates, who enthusiastically supported the League executive. ${ }^{2}$ Such delegate meetings had been used regularly by George Potter and his London Working Men's Association, and the League itself had found them useful in support of the II February demonstration. Now they became a regular feature of League machinery for about months. In May the General Council of League delegates only re-appeared, meeting weekly and totally subservient to the executive. No item of business, according to the General Council minutes and the newspaper reports, was initiated except by members of the executive, functioning on behalf of the executive. Only one controversial discussion developed. The Council largely spent its time approving executive reports and recommendations, voting thanks to Reformers and supporters, and listening to lengthy plauditory speeches by Beales. ${ }^{3}$

For functional and administrative support, and for at least the pretense of drawing authority ultimately from the total membership, the fiction of a general assembly had to be preserved by the executive. For special policy support an extraordinary meeting or conference served better, especially as the departments outside London grew. 4 The provincial departments and branches did not send regular delegates to the General Council, but did have special representatives in

1 Minute Books, General Council, 2 and 9 January, and Executive Committee, 4 January.

2 The Minute Books do not have full reports on the delegate meetings, which were reported more carefully in the sympathetic London papers.

a Minute Books, Delegate Meetings, 27 February, 13 March, 27 March, Io April, I May. There are no minutes for io April; merely a notice of the meeting having occurred. The executive apparently decided not to have a second one in April, but I can only infer this from the comments. On 18 April the executive decided to end temporarily the delegate meetings; that of I May would be the last. Minutes for the General Council exist for 8 May again.

- In April, i866, there had been 5I provincial branches of the League. By November there were 177 . By January, 1867 , there were well over 300 . I have used lists appearing in League pamphlets. 
London for certain occasions, such as great demonstrations and delegations to politicians.

The first League conference, not in conjunction with any other major event, was held on 28-29 February 1866 in London; about 200 League and supporting organization delegates attended, 38 of them from 22 provincial branches of the League. ${ }^{1}$ The conference was an attempt to initiate a League Reform bill, but it failed. Beales won approval, however, for a scheme of nation-wide League organization based upon methodist-type classes and class leaders, collectors, lecturers, and monthly delegate meetings, but little of this was initiated on such a scale.

On 23 July the London executive again sought closer associations with interested groups in and out of London and with League branches. ${ }^{2}$ The conference, quickly called, served no purpose except to have provincial delegates present for the Hyde Park disturbances which brought the name of the League into all newspapers and encouraged provincial branches.

The third conference called by the League executive was the most satisfying source of authority. Since Hyde Park and the coming to office of the Tories the provincial branches had expanded impressively, and were often following local, independent patterns of agitation. However, Parliament would open in February, 1867 , and the League planned a conference of provincial delegates in conjunction with a mass demonstration. The conference met on 12 February, and voted a significant resulution which acknowledged the guidance of London.

"We, the undersigned country delegates, having full confidence in the wisdom and prudence of the President and Council of the National Reform League, resolve, on behalf of our various constituencies, to continue to be guided by, and to co-operate with them in further prosecution of the great question of Parliamentary Reform, the settlement of which is essential to the peace, prosperity, and happiness of the nation. And we now call upon the whole people to assert their unqualified determination never to rest contented until full justice be done to them as regards their electoral rights."

Representatives of four of the major departments of the League, of the Irish Reform League, and of fourteen separate branches signed the document. The North Eastern Department (Newcastle) was not represented at the conference because Joseph Cowen was ill, and had

1 Commonwealth and Bee-Hive, 3 March 1866.

2 Bee-Hive, 28 July I 866.

3 Commonwealth and Bee-Hive, 16 February 1867 . Both gave the text. 
not arranged for a substitute delegate. Other branch delegates approved of the declaration, but left the meeting before signing in order to catch trains. With no real control over its provincial departments and branches the London League could nevertheless claim now more effectively to be representing a national movement. Simultaneously, the London executive was making use of those broader delegate meetings in London for general support.

The actual governing unit in the Reform League was the executive, operating under various designations and arrangements. The first large council elected by the public meeting of 23 March I $865 \mathrm{im}-$ mediately appointed from among its members a "Permanent Council" of twelve: Beales, Mason Jones, Montague Leverson, Charles Elt, David Chinery, the Rev. George Murphy, J. H. Longmaid, George Odger, George Eccarius, G. W. Wheeler, J. Whitlock, and William Stainsby. ${ }^{1}$ In May E.D. Rogers replaced Murphy, preserving the balance of six middle class and six artisan Reformers. In June J. Baxter Langley and J. Whitford, doctor and working man respectively, brought the executive up to fourteen. Howell, now general secretary, was automatically the fifteenth member.

By August the Permanent Committee had been absorbed again by the larger council, and in October Rogers demanded the changes which led to the twenty-four man executive created out of the previous large council. The "Executive Committee" then inaugurated a larger assembly called the General Council, as described. The new Executive Committee was still controlled by the LTC artisans and their middle class associates, and they administered the League in this form until the autumn of 1866 , when increased obligations disordered the vague responsibilities for decision. ${ }^{2}$ A suggestion for an executive of only five was rejected, but a comprehensive reorganization was carried out in September. ${ }^{3}$ The General Council elected by ballot a fifteen-man executive from among its members, and ordered that the four officers would be ex-officio members. E. D. Rogers, Colonel Dickson, George Odger, J. B. Leno, James Cunnington, W. R. Cremer, Benjamin Lucraft, J. J. Merriman, George Mantle, J. Baxter Langley, Charles Bradlaugh, J. Osborne, John Weston, George Davis, and Thomas Connally were elected in that order. In the balloting George Potter

1 Minute Books, Executive Council, 21 April 1865.

2 Ibid., 6 October 1865 . Howell was instructed to draw up a list of the twenty-four most attentive councillors, who would thus become the Committee. Names are not given in the minutes nor the newspaper reports, but it is obvious to what extent the LTC men now dominated from the part they took in previous meetings. Besides, Howell drew up the list. a Re-organization was discussed and then carried out on 7, 14, and 28 September. See Minute Books. 
had tied for the fifteenth place with Connally, but withdrew since Connally was a Potter supporter. Of those elected, seven were middle class and eight were artisans; the two men at the top of the poll were middle class, with Odger third. On the whole executive the middle class members outnumbered the artisans ten to nine.

With the Executive Committee of September, i 866, relative efficiency characterized the League administration. The committee met once a week on Fridays in the first few weeks, and then met on both Wednesdays and Fridays. In January, 1867 , the executive decided that Howell could call it together whenever he thought it expedient, but that it should meet regularly on Monday, Wednesday, and Friday. ${ }^{1}$ During times of particular excitement such as February (the opening of Parliament) and May (public demonstration in Hyde Park) of 1867 the executive met nightly.

In January the executive avoided the attempt of the General Council to re-gain direct control of the League, and the executive committeemen elected in February were not significantly different from those of September. ${ }^{2}$ Because of a decision not to allow anyone doing paid or contract work for the League to sit on the executive, J. B. Leno, the printer-poet, and J. Osborne, a metropolitan agent for the League, were ineligible. Cunnington had already resigned over some irregular League procedures in Manchester, where some of his Liberation Society colleagues were not happy with the Northern Department of the League. ${ }^{3}$ Only one man was defeated in February for the executive: George Davis, a printer and temperance reformer. Dr. T. W. Perfitt, R. A. Cooper, J. Guedalla, and A. J. Bannister replaced these four; only Bannister was a working man. Perfitt was an unaffiliated preacher and lecturer, Cooper a City businessman, and Guedalla apparently a businessman of some sort. Toward the end of the Reform agitation Charles Bradlaugh resigned from the Executive Committee because he feared his rationalist ideas would damage the League; there were no further changes in the executive before August, I 867, when the Reform Act became law.

After 186 , the executive of the League was rarely the scene of factional arguments, for the LTC artisans had less internal opposition from George Potter and his supporters. Potter eventually annoyed

1 Ibid., Executive Council, I I January.

2 Ibid., General Council, 2o February.

s Beales apparently helped F. Milne Edge with London League funds, and Edge worked at establishing a League office in Manchester. Cunnington almost certainly preferred the National Reform Union to the League, and objected to this challenge to the NRU in its base city. Beales explained the advance to Adge in a letter to Howell dated 27 September 1866. 
even the mild-mannered Beales, giving all the advantage within the League structure to the LTC and their friends. Also, the executive worked out its own functional problems under the pressure of events. Temporary subcommittees were frequently appointed from among the executive for specific tasks: to plan demonstrations, to plot lecture schedules, to report on problems of publicity or a contemplated statement of policy, or to plan election activities. Standing committees were considered, and both in January, I 866, and February, 1867 , the executive created "ways and means" and policy committees. These might have served as inner executive units, but they disappeared within three weeks of their creation. ${ }^{1}$

One standing committee did exist from I 865 to I 867 , and considerable executive power collected to it. The Finance Committee of the executive was probably elected in the first few weeks of the League's existence, but seems to have done very little work before September. Dell, Montague Leverson, and William Stainsby were members in June, and the committee was given the special task of approaching trade unions which were sympathetic to League objectives. ${ }^{2}$

The Finance Committee after September, 1865 , became a crucial part of League machinery, and it came under the firm control of $\mathrm{E}$. D. Rogers. Rogers had been a Common Councillor of the City, and came to the League through his interests in the Garibaldi visit and in the Universal League. He joined the executive of the Reform League in May, and in four months was elected to the Finance Committee and made its chairman. Howell as secretary was required to submit weekly accounts to Rogers, who received, checked, and approved them. Rogers consequently was the main defender of Howell when he was criticized. Because League funds were short, and because all activities naturally required expenditure, Rogers was closely involved in all decisions made by the League. Rogers' committee received a variety of tasks, not all of them directly financial. For instance, J. R. Taylor, elected with Rogers, and William Stainsby were responsible for contacting temperance societies on behalf of the League. ${ }^{3}$ And on at least one occasion the Executive Committee made the Finance Committee and some temporary assistants a "Joint Finance and Demonstration Committee".4

1 Minute Books, Executive Council, 26 January I866, and Executive Committee, 22 February and is March 1867.

2 There is evidence in the minutes that Mason Jones was serving in April as one member of a finance committee, but no certain evidence of such a committee until 30 June $186 \mathrm{~g}$.

- Minute Books, Executive Committee, 22 September and 20 October I865.

- Ibid., Executive Committee, I 8 August 1866. 
Rogers constantly argued for a more closely-knit and centralized League. He initiated the reorganizations of October, 1865, and September, 1866 . By the end of 1866 he was chairman of the executive, and resisted the General Council in January. He submitted the Second Annual Report of the League to a delegate meeting in April, I867, but then took less and less interest, attending irregularly and often begged by Howell to come when crucial issues were to be discussed.

At the top of the League structure were the four officers. The two treasurers were not of much importance. The executive elected Nicholay as treasurer, but his constant illnesses made it difficult for Howell to get formal approval for petty expenditures. In August, 1866, William Dell, who had helped to finance George Potter's Bee-Hive but was now at odds with Potter, was elected joint treasurer with Nicholay. Both men were ex officio members of Rogers' Finance Committee, but that whole committee, or its chairman, assumed control of most financial decisions and arrangements.

The secretary was a far more important official, perhaps the most important single functionary in the organization. In the first few weeks the Reformers decided to appoint a paid general secretary in charge of the central headquarters, and the council elected George Howell. The appointment caused considerable difficulty for the League. For peace between the factions, Howell was far too closely identified with the LTC and the IWMA, and his election was confused enough to encourage suspicion. Robert Hartwell had served initially as provisional secretary. He himself had proposed the appointment of a general secretary, which makes it sound peculiar for the Bee-Hive later to claim that he did not have in mind a paid functionary. ${ }^{1}$ The question of the secretaryship was referred to a subcommittee of Montague Leverson, Weston, and Howell, which reported to the executive on 22 April and recommended F. Milne Edge. Edge refused, and Howell was asked to act provisionally. The suggestion was later made that the Rev. George Murphy and Howell act jointly as sectetaries, but Howell insisted that the responsibility should not be divided. On 24 May he was appointed as general secretary, at a weekly salary of 34 shillings, something less than he had been earning as bricklayer. ${ }^{2}$

Hartwell was later to claim that Howell's election as secretary was a plot to put an LTC man into a key League place, an accusation which Beales and Howell both emphatically denied. ${ }^{3}$ Hartwell said there

1 Bee-Hive, is April 1865 and 8 December 1866.

2 Minute Books, Executive Committee.

3 Besides the Minute Books, the Bee-Hive of 15 and 22 April 1865 reported the election of Howell. Also, the newspaper on 8, 15, and 22 December 1866, and S January 1867 
had been no mention of a paid general secretary, or he would not have withdrawn as provisional secretary. And in the second place, he and his group would have supported another candidate. Beales and Howell insisted that all had been properly done, but Howell's story in his autobiography, admittedly written a quarter of a century later, tells of a deputation urging him to become secretary even before the preliminary meetings in St. Martin's Hall. Howell's sequence may have been wrong, but surely he remembered correctly that a deputation had approached him. His election would then not be quite the accident of circumstances he claimed at the time, but the result of a play at factional politics.

Howell was about thirty-two years of age when he became secretary of the League, self-educated, with limited experience in the methodical pressure politics of agitation. He was expected to do the work at the central office: carry out all commissions of the executive, correspond with the branches and with provincial groups interested in forming branches, answer any inquiries, solicit funds, help with demonstration plans, keep the financial records. The work grew in volume, especially as the number of provincial branches increased and the executive began to arrange for more demonstrations and public meetings. Before the end of the first year Howell had clerical help, but did not know to make the best use of it.

He wrote sometimes as many as fifty letters in a single day, but like a petty bureaucrat insisted that the remotest detail come to him before being passed on. He was unnecessarily abrupt with W. R. Cremer and James Finlen, paid lecturers and agents of the League who sometimes ignored Howell's letters and sometimes criticized him. Howell also became difficult about Edge, who had an irregular connection with the executive before he became secretary of the Northern Department of the League in Manchester. It was admittedly Howell who was perpetually on Potter's griddle of criticism in the Bee-Hive, and there were Potter men on the executive and General Council who were ready to attack the secretary over the slightest matter. He was forced to be immensely careful.

Throughout his tenure as secretary Howell was quick to take offense at any implied criticism, or even possibly implied criticism. He was exceedingly sensitive about others' opinion of him, and quickly assured even occasional correspondents how hard he worked, how carefully. Uncertain of himself, eager to please and impress especially the middle class reformers in the League, ambitious in his own way,

printed the Potter-Hartwell version of events, and rejoinders by Beales and Edge. Howell comments in his manuscript autobiography. 
Howell worked willingly at his tasks, pleased to be at the center of affairs. He was relatively able, earnest in a way which suggests selfcenteredness, but annoying in his self-justification. No evidence in the League records suggests dishonesty on Howell's part, though there are irregularities which, together with his personality traits, might lead to a suspicion of petty manipulations to his own and his faction's advantage. His position with the Reform League was a major step for Howell from bricklaying to semi-professional administering of "Lib-Lab" pressure groups. In short, he became an effective lobbyist. In $188 \mathrm{~s}$ he was elected to the Commons for Bethnal Green. ${ }^{1}$

Finally, at the peak of the League structure was Edmond Beales. From 1862 to 1865 Beales was increasingly involved with London artisans, and especially the LTC group, in various agitations and campaigns: the Trades Union Manhood Suffrage and Vote by Ballot Association, the Garibaldi visit, temperance societies, the pro-Federal and emancipation meetings, the Universal League, and his own special concern, the National League for Polish Independence. Beales, together with Mason Jones, approached Potter in January, 1865, and encouraged the calling of the public meetings which established the Reform League. And he encouraged the artisans to carry on by themselves after they had, in their opinion, been abruptly repudiated by John Bright in March.

The Reform League was fortunate in its president. Beales' right to the office in the first instance, and his ability once he had become president, were never doubted. In the regular, day-to-day discussions of the executive and the General Council Beales remained silent, arbitrating as he could between factions and among the diverse personalities. Cremer, Howell, Bradlaugh, Lucraft, and many others were capable of hard, effective work, but wanted to do everything, and often at once. Beales' sense of what was of real importance to achieving Reform was unique within League councils. In the first months he cautioned the League again and again about sponsoring elaborate, expensive public meetings when means were so limited. He emphasized in the first year opening metropolitan branches, collecting funds, preparing a base for the agitation which could matter. Again, in the spring and summer of 1866 Beales convinced the

1 My re-construction of Howell's personality is of course based upon the mass of evidence in the Howell Collection. More than anything else, the League carbon books, with copies of presumably all the letters Howell sent from the central office, reveal most about him. Particularly to League acquaintances in the provinces he indulged frequently in defensive commentary - and most especially in December, I866, when the Bee-Hive articles were running. 
League to support the limited Reform measure of the Russell Government, despite the obvious inconsistency with League principles. $\mathrm{He}$ realized that compromise in this case was crucial. The meagre support the League received from Liberals and Radicals was vital. The League held its rank-and-file after this compromise, in spite of the angry reactions of Ernest Jones in Manchester and more enthusiastic members of the executive council. ${ }^{1}$

Beales was eternally the careful arbiter among the more violent members of the two major factions in the League, the "Potter" faction on the one hand and the LTC faction on the other. The latter was in a majority from the first elections to the Executive Council. In June, I865, Beales as chairman of an arbitration committee between Potter and Odger exonerated Potter, who had been accused of bad faith and trickery. ${ }^{2}$ In August of the same year Potter's Bee-Hive attacked the League elections of the executive and secretary as irregular. Beales first persuaded the executive from extreme reaction, and then himself wrote a moderate letter of denial. ${ }^{3}$ In April, August, and November of 1866 Beales was confronted with perhaps the bitterest phase of the continuing row between the two factions. At issue was the question of an official League newspaper. For Potter and his supporters this was the ultimate challenge, and they succeeded in preventing an official League endorsement of the Commonvealth. In July and August, I 866, Beales spoke at meetings called by Potter's LWMA, but six months later the wild accusations filling the Bee-Hive had exasperated even Beales. After a series of letters reprimanding the paper for renewing useless grudges, Beales stopped trying to moderate.

Beales' job of conciliation was not made easier by Howell, who was intimate with Odger and loyal to the clique Odger helped to lead. Beales occasionally reproved Howell about his partisanship, as shown in a letter Howell wrote to Beales after one fray with Potter:

"You sometimes accuse me of temper in treating of these things.

Well be it so. But I never mean to change your leadership for George Potter's, nor will I consent for the League to do so."4 Howell, though perhaps right about Potter and his ambitions, could be annoyingly petty.

A sort of balance was kept in the League, helped out by the quick turn of events as the Liberals tried and failed to pass their Reform

1 Jones actually resigned from the League in May, 1866, and copies of two of Beales' pleading letters are in the Letter Books, dated 22 May and 2 June. The fall of the Russell Government solved the problem.

2 Bee-Hive, 24 June 1865 .

3 Minute Books, Executive Committee, I I August I865, and Bee-Hive, I 2 August I865.

- Letter Books, 26 December 1866. 
Bill, as the Hyde Park "riots" kept the League in the public eye, and as the Tories moved toward a Reform bill of their own. Had the pace of Reform in 1866 and 1867 been a bit slower, not even a Beales could have kept the factions together. At the same time, the League agitation helped to keep the Reform pace fast.

Beales suffered for his work in the Reform League. In 1866 , he was not re-appointed as Revising Barrister for Middlesex. The income was not significant, but the implication of the deprivation was that his politics would affect his judiciousness. Beales lost most of his legal practice, not entirely from reaction to his removal as Revising Barrister but also because he threw himself so totally into the Reform agitation. The League took an increasing portion of his time. In the five months from September, I 866, through January, 1887 , he alone spoke at over fifty provincial meetings, and many more in London itself. The $\mathfrak{E}_{\text {I I }}$ given him as a testimonial could not have compensated for his time and work of about a year, when the League was a full-time job. Besides, in the early months of the League's existence Beales had paid the rent on the Adelphi Terrace offices out of his own pocket. ${ }^{1}$ He and Mason Jones together had guaranteed the rent, but Jones in a huff quit the League before the autumn of 1865 , and never paid his part of the obligation. ${ }^{2}$

A primary question about the general administrative structure of the Reform League is whether it reflected the real leadership and initiative within it. The minute books and newspaper reports prove that as a rule it did. The five men who exercised most influence in London were Beales, the president, Howell, the secretary, Rogers, the finance committee chairman, Odger, an executive councillor throughout, and Lucraft, who appeared on the executive early in I866. Besides their own work within the councils of the League, Beales and Rogers provided links with middle class reformers, and Howell and Odger with LTC support. Lucraft was a stronger influence in the League in 1866 and $\times 867$ because he was a more radical agitator, and appealed for support beyond the LTC artisans, without identifying himself with Potter, their bitter opponent. Below these five men in influence were five others: Baxter Langley, Col. Dickson, Leno, Cremer, and Bradlaugh. Of these, only Cremer was clearly an artisan. The remaining executive councillors and officers are not to be dismissed as unimportant. They were active and frequently vitally influential, but did not exercise the same sort of continuing leadership as the ten men above.

1 Letter from F. Milne Edge, Bee-Hive, is December I866. Beales confirmed the information in a reply on 22 December.

Howell's manuscript autobiography. 


\section{III}

The source of funds to support the machinery of the League, and the use of these funds, were fortunately documented in moderate detail for the years of the Reform agitation. The annual reports of 1866 and 1867 , submitted in April, and the half-yearly report of October, 1867 , together with ledgers and account books, give enough information for a general summary of League finances. ${ }^{1}$ Rogers, chairman of the Finance Committee, presented the reports, but they were largely the week-to-week work of Howell. Howell, as in most of the things he did for the League, was often feeling his way and adapting to his experience. Income from collections at demonstrations and metropolitan meetings, for instance, appeared only in the Second Annual Report, and is presumably absorbed elsewhere in the earlier report. The names of donors were not kept systematically. Names and amounts given must often be pieced together from ledgers, letter books, minute books, and printed fly sheets.

Total income for the League in its first two and one half years was $£ 4420$. About $£ 620$ came in during the whole of the first year, and in the second year the income was just over £ 3100 . From April to October, 1867 , it was near $£ 700$.

Membership contributions provided about $£_{\text {I } 200}$ for the League, almost $£ 650$ of this in the second year alone. There is no clear breakdown of the income from subscriptions, which were given annually, and membership fees, which were paid weekly or monthly. Certainly, $£ 250$ were paid in annual subscriptions of one to five pounds, and seem to have come largely from vice-presidents of the

TABLE I: INCOME, I865-1867

\begin{tabular}{|c|c|c|c|c|}
\hline & Total & $1865-66$ & $1866-67$ & Apr.-Oct., 1867 \\
\hline Memberships, subscriptions, etc. & $£$ I 200 & $£ r_{40}$ & $£ 650$ & $£_{410}$ \\
\hline Donations & 2720 & 475 & 1960 & 280 \\
\hline $\begin{array}{l}\text { Miscellaneous (sales of pamphlets, } \\
\text { collections, advances) }\end{array}$ & $4^{\circ}$ & 5 & 30 & IO \\
\hline Beales Testimonial Fund & 100 & & IOO & \\
\hline Hyde Park Defense Fund & 360 & & 360 & \\
\hline Totals & $f_{4420}$ & $£ 620$ & $f_{3100}$ & $£ 700$ \\
\hline
\end{tabular}

(Sources: Annual and Semi-Annual Reports, 1865-1867, corrected and extended from Ledgers, Account Books, and some information in Letter Books. For convenience I have taken the sums to the nearest pound.)

1 All three are in the miscellany of the Howell Collection, and can be used along with the Ledgers and Account Books, pamphlets, and Letter Books. 
League or other middle class supporters. Professor Goldwin Smith, Jacob Bright, Mrs. P. A. Taylor, Benjamin Whitworth, and George Julian Harney, for instance, each paid a $£$, annual subscription. A good many working men contributed annually, but probably little (if any) more than the one shilling originally prescribed in League rules.

Most working men preferred to contribute monthly or weekly. The monthly contributions of a penny became in some instances weekly penny contributions as the metropolitan branches decided to collect more than the prescribed annual shilling. The executive treasury realized $£$ soo from these weekly and monthly fees. Howell must have sold some membership cards from the central office, but as a matter of policy the League in general sold cards through the branches. Branches were to pay $4 \mathrm{~d}$. to the national office for each shilling card sold. But when cards were sold for something like $4 / 6$, the executive must not have received more than the agreed $4 \mathrm{~d}$. The provincial branches paid almost $£ 300$ to the executive as the third on shilling cards. No evidence indicates that the Midland Department (Birmingham), Northern Department (Manchester), Yorkshire Department (Leeds), North-Eastern League (Newcastle-upon-Tyne), Scottish National Reform League, Worcester League, Bristol League, and Oxford League paid any percentage at all to the executive. These departments and branches issued their own membership cards.

Donations, both from wealthy participants in the League and interested supporters, kept the League alive. Well over twice as much, or about $£ 2720$, was realized from donations than from subscriptions and fees of all sorts. These donations provided half the League's total income. In its first year, when it was struggling to open first a metropolitan and then a national agitation, donations of $£ 475$ provided more than two-thirds of all income.

Richard Cobden, just before he died on 4 april i 865 , may have given early and important help in soliciting contributions.

"Mr. Richard Cobden... was favourable, and had he lived it is probable that his manly eloquence and his influence would have been used in favour of the Reform League. However, his well known sympathy was of service in the earlier stages of the formation of the League, and especially in regard to subscriptions, with such men as Professor Cairnes, William Hargreaves, A.W. Paulton, Frederick Pennington, T.B. Potter, Samuel Morley, and others."'1

Cobden's sympathy was not quite so well known as Howell imagined years later, but if he put in a word with the men Howell listed, the

1 Manuscript autobiography. 
sympathy was helpful. Each did contribute. A good word with Morley alone meant a great deal.

It was P. A. Taylor who helped with a public gesture to begin the donations. ${ }^{1}$ Taylor offered $£ 2$ s to the League, on the condition that several other contributors could be found who would each match his sum. The list of seven was not completed until early 1866, and included Morley, Sir Wilfrid Lawson, Samuel Plimsoll, Samuel Pope, Rigby Wason, William Hargreaves, and T. B. Potter.

The largest single contributor to the League was Morley, who gave at least $£ 425$ during this time. In other words, the wealthy Morley, whose connections with dissent, temperance, and Manchester Radicalism were additionally valuable to the League, was the source of about one-tenth of the League's income to October, 1867. Morley might have been influenced by Cobden. At the Radley Hotel conference on 16 March 1865 he promised support, but took several months to follow through with a donation. According to Howell, he was not at all cooperative when first approached about a contribution, but quickly changed his mind, or mood. This was, however, after Cobden's death. ${ }^{2}$

Another large contributor was Sir Wilfrid Lawson, who died in I 867, and whose son, also Sir Wilfrid, was notorious for his persistent advocacy of "permissive" temperance legislation. Lawson, the father, gave over $£ 300$ before his death, and the son another $£$ roo. Both were ardent temperance advocates, and the father an avid dissenter.

Morley and both Lawsons were vice-presidents of the League, but several important contributors were not. Titus Salt of Saltaire in February, 1867 , sent $£ 200$ to the Executive, having given some rather vague promises of support a few months before. Another Bradford man, Robert Kell, seems to have done most to obtain Salt's contribution. Kell and his brother Samuel themselves gave another $£$ i I 5 . Both were active in the NRU. Robert Kell, or T. B. Potter, or perhaps both, apparently in late 1866 and early 1867 did a great deal of work for the League among Bradford men. Potter gave Howell a list of likely contributors. ${ }^{3}$ The League collected $£ 4$ I 5 from this group alone in January and February, 1867 , and much of it had been promised earlier. Alfred Illingworth, Alderman Godwin, Alderman Brown, John Drummond, and N. Briggs sent from $£$ io to $£ 50$. The Bradford men, while themselves household suffrage advocates, still saw an opportunity to put pressure on the Conservatives and Whigs by encouraging the League with Radical money.

1 Minute Books, Permanent Committee, 2I July I869.

2 Manuscript autobiography.

- Minute Books, Executive Committee, 22 February 1867. 
Other names appear in the ledgers or minutes as contributors of sums ranging from Pennington's $£$ I 45 to Montague Chamber's $£$ s. Thomas Thomasson gave $£$ roo; William Hargreaves, $£ 90$; and A. W. Paulton, £ 6o. Two M. P.'s, Isaac Holden and P. A. Taylor, were $£$ so donors. Sir Isaac Hoare, John Holms, and R. A. Cooper gave about $£$ so each.

The Reform League records cannot possibly tell the entire story of financial support, since there is no evidence of contributions directly made to provincial departments and local branches. Joseph Cowen, Jr., spent a great deal of his own money on the North-Eastern League in Newcastle. Howell, at least, thought the Northern Department in Manchester was dealing in "hundreds of pounds." Occasionally Howell mentions local men paying the few pounds of expenses for local meetings, and contributions taken at lectures helped keep agents from London on circuit throughout i 866. The League was never highly centralized, and it is impossible to know how much was actually spent in its name by the branches numbering at least 619 (I 44 in London, 354 provincial, I 28 ward, 23 "auxiliary"). Rogers estimated that $£$ I000 had been spent there in $1865-66.2$

Though involving League political connections as much or more than League finances, the list of members of Parliament who contributed something to the League is of interest: Chambers (Devonport), Holden (Knaresborough), Lusk (Finsbury), Torrens (Finsbury), Hughes (Lambeth), J. S. Mill (Westminster), Potter (Rochdale), Taylor (Leicester), Stansfeld (Halifax), Whitworth (Drogheda), C. Salisbury Butler (Tower Hamlets), C. W. Dilke (Chelsea), G. H. Whalley (Peterborough), Thomas Barnes (Bolton), the O'Donoghue (Tralee), Seely (Lincoln), and Bright (Birmingham). Morley was elected in 1865 , but unseated on petition in 1866 . Wilfrid Lawson had been defeated at Carlisle in 1865 , and Rigby Wason was an ex-M. P. for Ipswich.

The League did not enjoy a steady, reliable income. Collecting funds at the necessary moment became, then, of primary importance. There was never more truly a hand-to-mouth existence for a political association. After the great effort of the demonstration on II February I867 at the opening of Parliament, for instance, activities had :o be drastically curtailed for lack of funds.

Cobden may, as mentioned, have helped the League at first with a word here and there to wealthy Radicals. Once the League was

1 Letter Books, Howell to Beales, 6 October 1866.

2 First Annual Report. 
underway Beales and Mason Jones "made arrangements to wait upon several friends who had promised support." Advances from several of the active members of the League helped get it under way. Leverson and Wheeler both advanced money for the offices. Beales paid the rent on the Adelphi Terrace headquarters for several months in 1865 . Other members gave furniture and equipment. Leno did some printing without charge.

By June, 1865 , the first donations gave the League a few pounds upon which to operate, and subscriptions were trickling in. From July soliciting activity noticeably increased. The League now realized it would take persistent work to bring in even a minimum income for the agitation. Printed letters congratulating the successful Liberals were sent after the 186, election; aid for the League was also asked. ${ }^{2}$ The Finance Committee was specifically told to get in touch with every man who had promised aid to the League, and J. R. Taylor was added to the Committee in order to help solicit funds. ${ }^{3}$ Within a week of these decisions P. A. Taylor made his offer of a donation, if matched by seven others. Though it was January, I866, before the list of eight was completed, several paid earlier. Morley, who "seemed surprised at our presence as he understood from Mr. Mason Jones that the League was an abortion", paid a cheque to Howell before the autumn demonstrations of $186, .4$ Sir Wilfrid Lawson and Hargreaves certainly sent $£ 25$ each in 1865 .

Howell as secretary had much to do with getting in funds. He seems to have made fruitful contacts with Morley. He was responsible for getting out circulars in late 186, to encourage contributions. The first such circular listed vice-presidents of the League, and the second announced Taylor's offer. He wrote letters to several notables asking them to consider Taylor's offer, including Alderman Heywood, Harper Twelvetrees, Edward Miall, Benjamin Whitford, Samuel Plimsoll, Benjamin Lusk, Lord Teynham, and others. Only Plimsoll responded. ${ }^{5}$

Funds came into the League much more readily after October, 1865 , when Palmerston's death brought Russell to office. Reform was a hot and ready issue now; the Radicals wanted all the aid they could muster, and especially in February and March when the struggle began in the Commons. League agents solicited funds, but Howell himself

1 Minute Books, Subcommittee, 2 I April 1865.

2 Ibid., Permanent Committee, I4 July i 865.

Ibid.

- Ibid., 21 July 1865 . Mason Jones broke with the League during the summer of 1865 , resigned in November, and was again a member in August, 1866.

- Letter Books, October and November, 1866. 
did very little soliciting until April, I866, when he began again to write letters requesting donations. League resources had been drained away by the activities of the winter and early spring.

In September, I 866, after the excitements over Hyde Park in the previous July, the League launched its " $£$ I0,000 Fund" in conscious imitation of the Anti-Corn Law League. ${ }^{1}$ Howell did most of the work, but the whole business flopped rather badly. Six men promised $£ 250$, if a total of $£ 5,000$ could be acquired. It was not acquired, of course, but Morley and Lawson did pay the $£ 250$ each. Probably about $£$ 1000 were realized as a result of this appeal. The " $£ 10,000$ Fund" was specifically intended for lecture tours to stir up the provinces, but nothing like a thousand pounds were ever spent on the lecturers. Funds collected for special purposes in the League were not much respected in League financing. Any money which came in was used for daily necessities. One special fund was respected. Some $\mathfrak{z}_{3} 60$ were given and used in 1866 for the defense of those charged after the Hyde Park disturbances.

By November the League financial situation was becoming desperate, at the very moment when more pressure was thought to be needed on the Tories. Howell made pleas to Morley, Potter, Pope, Taylor, and other bourgeois friends of the League. With Morley's permission he began to use Morley's name in his letters, not always with success. ${ }^{2}$ Thomasson sent a cheque, but Taylor apparently reacted with resentment to the appeal. Howell tried to explain the case:

"I was instructed to write to about Io gentlemen whose sympathies were well known to be with our cause, as we could not see how to keep up with anything like power our present agitation unless we had some good liberal help.

The fund of $£$ 10,000 had completely failed and our branches were drained with the great meetings held during the autumn. We wanted a fresh start, and more we wanted to be able to know our strength and compass our means. Hence my letter." 3 Howell, by such efforts, paid the debts and began to build up a fund for the greatest effort the League had yet planned, the demonstration of i I February 1867. The plans for the demonstration, and the effort itself, brought forth the Bradford money, which largely paid for II February. With very little in its treasury, though with its debts paid, the League faced the possibility of a spring during which the Tories

1 Ibid., Howell to R. C. Hanbury, M. P., 19 September 1866.

Letter Books, 7 November 1866 and undated copies (probably of same date).

s Ibid., Howell to P. A. Taylor, is November 1866. 
might balk, and together with the Whigs stop Reform. "We are, you know, trying to get our funds so as to be more active than ever," wrote Howell. "Our quietude was only until we could settle our debts." 1

In March, 1867, the chaos of authorized collecting agents was ended by the League executive. One man, Ctemer, was appointed to work with Howell. ${ }^{2}$ Howell resented this intrusion on the domain he considered his own. If the two did not already despise each other, there was at least healthy disrespect which soon resembled hatred. By the new arrangement Howell wrote letters to likely donors, and Cremer would than make further approaches. From the i $s$ th of March to the Ist of April Howell wrote nearly roo letters to Liberal M.P.'s, Radicals, and wealthy members of the League. Each letter was accompanied by an appeal from Beales, and two supporting letters. One such letter from Bright apparently emphasized the importance of the League; the second was from Morley. ${ }^{3}$ Not much could have been realized by this effort: perhaps $£ 250$. In the spring and summer Radical support rapidly dropped away from the League as the Reform Act was re-modelled on a household suffrage basis, which was the Radical programme. In July the League had three guineas in its treasury. By the time the Reform Act had become law, Howell was at work asking donations to the Registration Fund, which would help the new electorate get itself on the registers. In October some $£$ I I had been collected, and it was largely used to pay Reform agitation debts. The $\&$ so from Sir Isaac Hoare, for instance, ostensibly for the Registration Fund, immediately went to pay old debts, or at least the most pressing ones. ${ }^{4}$

Howell's part in getting money for the League was more important than the work of the paid agents, who were operating from September, I 865. The members of the executive had always been "authorized" to collect on the League's behalf, keeping $10 \%$ as a commission, but it was in September when Charles Murray, a joiner, was hired as a collector. ${ }^{5}$

Murray was to receive is $\%$ of what he collected. Six weeks after his appointment Murray had collected nothing; dishonesty was hinted by members of the executive. Some time around the turn of the year

1 Ibid., Howell to W. Osborne, 23 March 1867.

2 Minute Books, Executive Council, is March 1867.

' Letter Books, March, 1867. A copy of Beales' accompanying letter is among Letters

Received, 1867 . I have not found copies of Morley's or Bright's letters.

- Letters Books, Howell to Dell, 2 September 1867.

- Minute Books, Executive Committee, 8 September 1866. 
Murray was quietly dropped by the Finance Committee, which had originally hired him.

Again in 1866 , exactly a year after Murray's appointment, the executive tried again with a collector named Moorhouse. Moorhouse collected something, since he and the executive immediately disagreed about the commissions to be paid. Moorhouse was paid off, and for sometime complained of ill-treatment by the League. Bradlaugh on the League's behalf finally settled with Moorhouse, who had in fact worked very briefly. ${ }^{1}$

Besides Murray and Moorhouse there were confusions about "authorized" collectors until March, i 867. Finlen, Cremer, Odger, Connally, the Rev. Bonner, Dr. Perfitt, and Osborne, all of whom were paid lecturers or agents at one time, could collect funds and were allowed to receive commissions of $7 \frac{1}{2} \%$ or $10 \%$. Edge, who had refused the original offer of the League secretaryship, did some commission work in late 1866 , receiving a percentage of one of Morley's gifts. In February, I867, Edge claimed, and was refused, commission on Thomasson's donation of $£$ roo.

As stated, the whole system of collection was reorganized in March, I 867. All authorizations for collecting were withdrawn. Cremer alone was given a new authority. The League had already begun to drift beyond its Reform agitation, and was soon looking to another phase of its life, registration and electioneering. Funds tapered off, and Howell was increasingly at odds with Cremer. By September Howell wrote to Dell, "I am fast losing my control over the getting in of funds thanks to the Executive Committee led by Cremer and others."'2

Political circumstances governed the flow of money to the League more than administrative efficiency. Collection was haphazardly managed, but brought in the limited funds with the League managed so remarkably well.

In brief, the League spent its money as shown in Table 2.

Two items are not given in this accounting. One of these was the Defense Fund of $£ 360$, collected on behalf of and spent for the legal defense of those men charged with rioting after the Hyde Park disturbances of 1866 . The other item was $£$ IoO given by the League to the Beales Testimonial Fund for losses he incurred during the agitation. Still, the expenditures in Table 2, plus the $£ 460$ of these two items, plus the $£$ I $25_{5}$ in hand in October, I 867, leave $£ 345$ unaccounted for. How much, for instance, did Edge use to open the offices of the Northern Department in Manchester?

Ibid., Executive Council, 22 February 1867.

2 Letter Books, Howell to Dell, 2 September I 867. 
TABLE 2: EXPENDITURES, I865-1867

\begin{tabular}{|c|c|c|c|c|}
\hline & Total & $1865-66$ & I $866-67$ & Apr.-Oct., 1867 \\
\hline Demonstrations, public meetings & $£ \times 498$ & $£ 107$ & $£ I 27^{\circ}$ & $£_{I 2 I}$ \\
\hline Lectures & 189 & $\begin{array}{l}\text { not } \\
\text { given }\end{array}$ & 154 & 35 \\
\hline Printing, posters, advertisements & 843 & 132 & 527 & I 84 \\
\hline Salaries & 367 & 89 & 189 & 89 \\
\hline $\begin{array}{l}\text { Office, expenses (rent, postage, } \\
\text { supplies, etc.) }\end{array}$ & 576 & 197 & 249 & 130 \\
\hline
\end{tabular}

Very little money was paid from the central fund for branch meetings in London, and virtually none at all for provincial meetings other than lectures. The total listed for lectures does not give a true picture of this activity, since lecturers often collected enough on the evening to pay for the hall, publicity, travelling expenses, and perhaps lecturer's fee.

\section{IV}

A study of the administrative structure and the finances of the Reform League indicates two conclusions about the character of the agitation from I 865 , to 1867 . First, the League did little to create opportunities for itself, except to sustain some form of central organization which could take some advantage of metropolitan or national political events. Organized because of approaching elections, reorganized in conjunction with a new national political situation after Palmerston's death on 18 October 1865 , and reorganized again in the autumn of 1866 after the fall of Russell's Government and the Hyde Park "riots" had excited Reformers, the League was an organized pressure group which had some measure of greatness thrust upon it. The League did very important work, but it must be seen in this perspective. Second, the artisan Reformers paid a marked deference to the bourgeois Reformers in the League, electing them to numerous positions of leadership and relying upon their financial support to a great extent. Though occasionally speaking on platforms the words of class struggle, the artisans did not act accordingly when the bourgeois Reformers paid them any serious attention, or even begrudging compliments, as they were doing in the agitation of 1865 to 1867 . Reform Leaguers of any class saw Tories and Palmerstonian Whigs as the enemies. Artisan Reformers were not fighting capitalists, but were demanding their place in the old order. Only a few had even the vaguest notion of a new one. Artisans were prepared to meet and march in $1865-67$, but not to fight: what they gained in 1867 was equivalent to such attitudes. 